\title{
Irrigation and crop water requirement estimation for oil palms using soil moisture balance model in Peninsular Malaysia
}

Adesiji, Adeolu Richard a,b*, Nik Daud, Nik Norsyahariati a, Asogwa, Evarestus Osita b, Mangey, Jarumi Akila c, Musa, Hassan Hassan b, Adaudu, Ignatius Idoko b

aDepartment of Civil Engineering, Faculty of Engineering, Universiti Putra, Malaysia, 43400, UPM Serdang, Malaysia

${ }^{b}$ Department of Civil Engineering, Federal University of Technology, Minna, Niger State, Nigeria.

cWater Resources and Environmental Engineering Department, Ahmadu Bello University, Zaria, Nigeria

\section{ARTICLE HISTORY}

Abstract

Received: 31 March 2020

Received in revised form: 5

September 2020

Accepted: 7 September 2020

Available Online: 18 September 2020

\section{Keywords}

Runoff estimation

Oil palm plantation

Soil moisture balance

Hydrological models

Irrigation water demand
This study presents the irrigation and crop water estimation in a Malaysian oil palm plantation for effective irrigation water management during water years 2013 and 2014. The study area was divided into four plots: 2000, 2002, 2006 and 2010, indicating years of peat swamp forest conversion to oil palm plantation. Hydrologic Engineering Centre-Hydrologic Modeling System (HEC-HMS) and Soil moisture balance hydrologic models were used to model the rainfall-runoff in the basin. Statistical analysis using coefficient of determination $\left(R^{2}\right)$ and Nash-Sutcliffe efficiency coefficient (NSE) were used to evaluate the performance and correlation of the two hydrologic models. The result showed that $R^{2}$ and NSE were 0.94 and 0.90 respectively for calibration and 0.92 and 0.54 respectively, for monthly validation. This showed that the models performed well for simulation of the peatland hydrology. With the modelling of rainfall-runoff satisfied, the irrigation demand of the study plots was determined using the same soil moisture balance model. The irrigation demand ranged from 0.893 to 1.6 million cubic meters (MCM) in 2010 and 2000 study plots respectively. Irrigation demand is observed to be site specific which depends on the soil moisture deficit, readily available water in the oil palm root zone and oil palm rooting depth. Estimation of a future oil palm water requirement using the soil moisture balance model would be recommended for further studies for use as an advisory manual for the oil palm managers to enhance adequate water resources planning for oil palm productivity.

\section{Introduction}

Water resources management, especially in oil palm plantation, is of high significance considering the amount of moisture required for oil palm productivity. According to Harahap and Darmosarkovo (1999), oil palm is estimated to use water between $1.83-4.13 \mathrm{~mm}$ palm-1 day-1 for its production yield. This is far above the consumptive use of water by forest trees and annual crops (Schilling, 2007; Naderi et al. 2016). Cultivation of oil palms on formerly existing peat swamp forests in Malaysia and other oil palm producing Southeastern Asian countries has gained popularity owing to the high global demand for the oil palm products, especially palm oil bio diesel (Avinash et al. 2014). This high demand for the oil palm products thus led to conversion of peat swamp forests in those countries to oil palm plantations, especially in Indonesia and Malaysia. This conversion, however, did not come without its adverse effects as most of the trees in the peat swamp forest were felled in preparation for peatland agriculture (Kamlun et al. 2016; Adila et al. 2017). The peatlands thus became vulnerable to floods and eventual increase in surface runoff due to poor watershed management based on unreliable hydrological information along with rapid deforestation (Seo and Lee 2015; Kamlun et al, 2016). Due to deforestation and other anthropogenic activities in the peat swamp forests, peatland groundwater is lowered, which, in other words, enhance peatland agriculture for oil palm productivity (Querner et al. 2012; Katimon et al. 2013; Melling et al. 2014).
With lots of benefits derived from oil palm productions, sustaining these economic benefits is being threatened as best management practices (BMPs) to enhance its sustainability are not being practiced. The most important among these BMPs in the oil palm plantation is the soil water management, particularly of those oil palms cultivated on peat. According to Lim, et al., (2012), effective water management is the key to high oil palm yield on peat. To enhance oil palm productivity, therefore, adequate soil moisture at the root zones must be available as too little or too much of it will adversely affect nutrient uptake and fresh fruit bunches (FFB) yields of oil palms (May, 2012). This thus underscores the relationship between the surface runoff and soil moisture availability in the root zones. As water table depth (WTD) is being lowered due to peatland drainage, the crop water stress increases and the extraction of water from the root zones for crops use becomes more difficult. This explains why there is need for soil moisture availability in the root zones all year round which is only feasible when there is good water management put in place. Thus, according to Roundtable on Sustainable of Palm Oil (RSPO) (2012) and May (2012), a good water management system for oil palms on deep peat is one that can effectively maintain a water level of $50-75 \mathrm{~cm}$ from the peat surface for as long as possible. It should also be able to remove excess surface and sub-surface water quickly during wet season and retain water for as long as possible during dry spells.

This is where peatland hydrology and peat soil properties become very important. With adequate rainfall and minimum surface runoff, substantial percentage of rainfall known as 
effective rainfall would get to the root zones and become available soil moisture to the plants (Awulachew et al. 2009). Substantial part of this rainfall will also recharge the groundwater table thereby raising the water table depth and enhance adequate available soil moisture at the root zones (Rushton et al. 2006; de Siva and Rushton, 2007). Therefore, predicting water needs for irrigation is necessary for the development of an adequate water supply and the proper size of equipment. This is where crop irrigation design comes in which is mainly the estimation of crop water requirement (CWR) that would produce optimum crop yield. The focus of this paper is, therefore, to use Hydrologic Engineering Centre-Hydrological Modelling System (HEC-HMS) and soil moisture balance model to estimate surface runoff and irrigation water demand of oil palms in a Malaysian tropical peatland. Soil moisture balance model considers both the soil and crop properties of the study area being used in the soil moisture deficit estimation. Consumptive use of soil water by the oil palms compared to the available soil moisture known as total available water (TAW) during the period of no groundwater recharge was estimated on daily basis. This further helped in estimating the deficit in water balance in the soil and the precise irrigation need of the waterstressed oil palms.

\section{Methodology}

\section{Study area}

The study area is located in Sepang, the state of Selangor, Malaysia at Kuala Langat South Forest Reserve area, between latitude $02^{\circ} 43^{\prime} \mathrm{N}$ and longitude $101^{\circ} 39^{\prime} \mathrm{E}$ bounded to the West by Straits of Malacca (Figure 1). The study area experience tropical climate and high humidity with an annual rainfall between $2500-3000 \mathrm{~mm}$. The monthly air temperature ranges between $32^{\circ} \mathrm{C}$ and $36^{\circ} \mathrm{C}$, with the highest value recorded in May each year. For the 2014 water year under study, the lowest rainfall recorded was in February as $7.0 \mathrm{~mm}$ and highest in April as $437 \mathrm{~mm}$. The average annual rainfall for the study year, 2014 was $2348 \mathrm{~mm}$ from the Malaysian Department of Irrigation and Drainage (DID) gaging station 2918101 in the study area. The study ran from June, 2014 to December, 2014 (both months inclusive). During this study period, the highest rainfall depth observed was in November as $399 \mathrm{~mm}$. The vegetation of the study area is characterized with oil palms since the peat swamp forests were first converted to oil palm plantation in 1978.

\section{Site selection}

The study area located in Sepang with total area of 4,950 ha (49.5 $\mathrm{km}^{2}$ ) was divided into four different sub-basins, each subbasin named according to the years the peat swamp forests were converted to oil palm plantations, such as; 2000, 2002, 2006, and $1978 / 2010$. The latter was first converted to oil palm plantation in 1978 before it was re-cleared for cultivation in the year 2010. All the sub-basins have the same hydrologic soil type and same vegetation but with different catchment areas. To establish an hydrological parameters for the ungauged study areas, a basin with a recorded daily and hourly flow and rainfall data from gaging stations 2918401 and 2918101 respectively located along Semenyih river which lies within latitudes of $2^{\circ} 40^{\prime}$ $152^{\prime \prime} \mathrm{N}$ to $3^{\circ} 16^{\prime} 15^{\prime \prime} \mathrm{N}$ and longitudes of $101^{\circ} 19^{\prime} 20^{\prime \prime} \mathrm{E}$ to $102^{\circ} 1^{\prime}$ 10 "E was used in the study. The use of Semenyih catchment as a proxy site for runoff estimation using HEC-HMS Model became necessary due to the lack of real-time runoff data in the study area. Semenyih basin was chosen as it has the similar vegetation and soil properties with Sepang basin.

\section{Runoff estimation using recorded streamflow data and HEC- HMS}

HEC-HMS, version 4.1 (USACE, 2000), was used in this study to simulate the runoff hydrographs resulting from a design storm on Sepang oil palm plantation basin. It was also used in this study to develop a hydrologic model for Semenyih basin with catchment area of $35.38 \mathrm{~km}^{2}$. According to Chen et al., (2009), the model addresses the spatial distribution of catchment characteristics by subdividing a catchment into subcatchments that are treated as homogenous in land-use, soil type, etc. The resulting runoff from the HEC-HMS was statistically compared with the recorded streamflow data by adjusting model parameter values of HEC-HMS such as curve number $(\mathrm{CN})$ and lag time until the model results match acceptably the observed streamflow data. Having obtained the values of percent imperviousness, the values of CN and Lag-time were both inserted as input parameters in the HEC-HMS to obtain direct runoff which was then compared with the recorded flow.

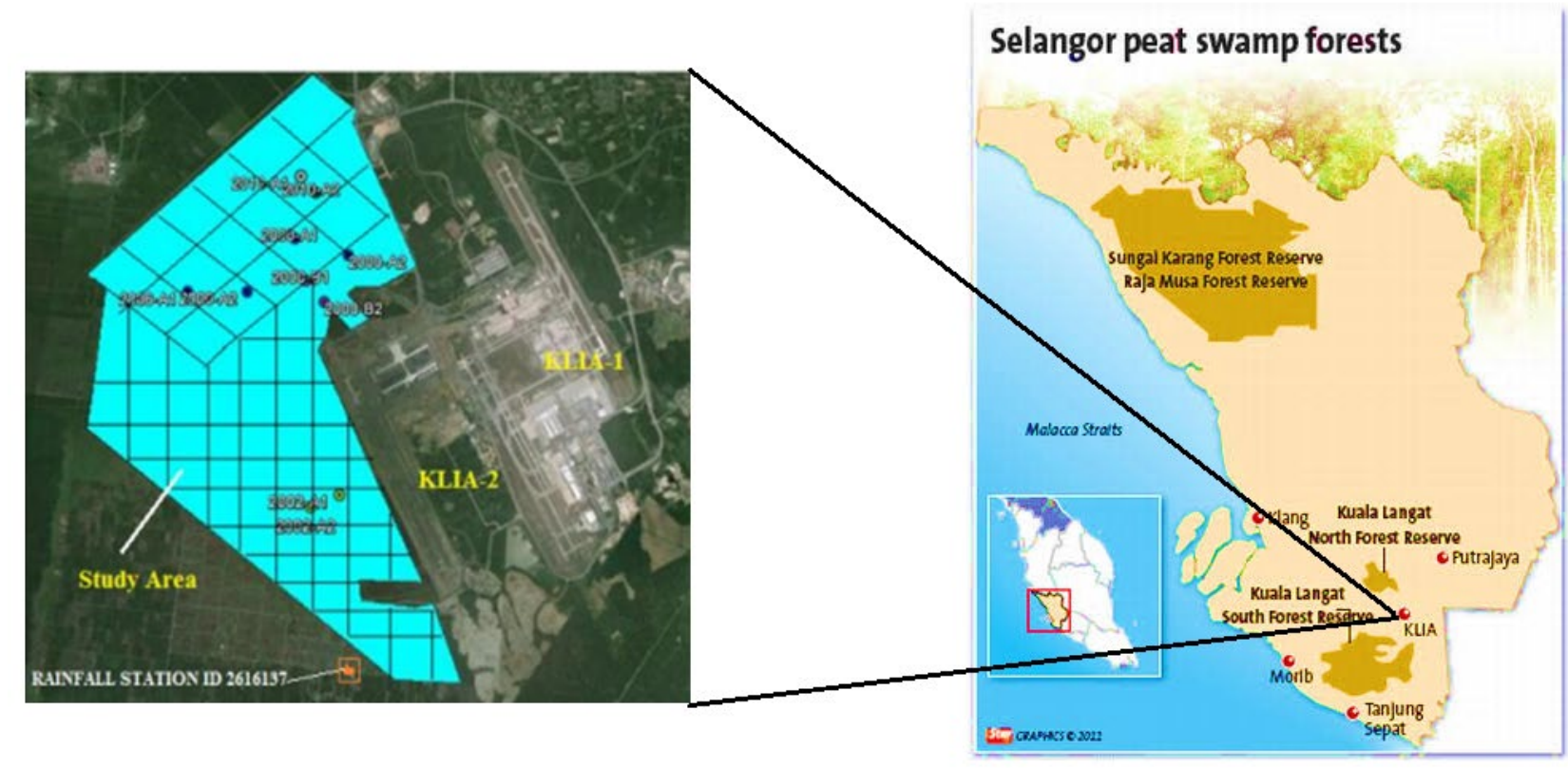

Figure 1. Location of study area with rainfall gauging station (Source: Abdulkarim et al., 2017) 
Statistical relationship was established between the flow data from HEC-HMS and recorded flow data from gaging station ID 2918401. Both hourly and daily flow and rainfall data covering 2013 to 2015 were obtained from Malaysian Department of Irrigation and Drainages (DID) and used in the runoff estimation. Two highest rainfall depths with simple hydrographs were chosen for the calibration of the HEC-HMS model. Hourly rainfall depths of April $7^{\text {th }}$ and November $23^{\text {rd }}$ 2014 water year were chosen for the calibration of the model while the months of September and December were used for model validation. Having established the flow data for April $7^{\text {th }}$ and November 23rd, the flow data from HEC-HMS and the recorded flow data from gaging station ID 2918401 were tested for model performance using both the coefficient of determination $R^{2}$ and Nash-Sutcliffe model efficiency coefficient $\left(E_{N S}\right)$ (Dongquan et al. 2009; Karthikeyan et al. 2013).

The Nash-Sutcliffe model efficiency coefficient is used in assessing the predictive power of hydrological models, and it is defined as (1)

$$
E=1-\frac{\sum_{t=1}^{T}\left(Q_{o}^{t}-Q_{m}^{t}\right)^{2}}{\sum_{t=1}^{T}\left(Q_{o}^{t}-\overline{Q_{o}}\right)^{2}}
$$

Where;

$Q_{o}=$ mean of observed discharges, and

$Q_{m}=$ modeled discharge and

$Q_{o}^{t}=$ observed discharge at time $t$.

Nash-Sutcliffe efficiency ranges from infinity to 1 . The value of efficiency of 1 (when $E=1$ ) means there is a perfect match of modeled discharge relative to the observed data. The value of efficiency equal to (when $E=0$ ) shows that the predictions of model are as accurate as the mean of the observed data, whereas an efficiency below zero $(E<0)$ occurs when the observed mean is a better predictor than the model.

\section{The soil moisture balance model and its computational method}

In this study, a single layer soil water balance model that incorporates the physical processes such as: rainfall, surface runoff, evapotranspiration, crop transpiration, root growth, soil water distribution following rain event and potential recharge developed by Rushton (2006) is adopted. This soil moisture balance model with supporting input data listed has proved to be a strong and flexible method of potential surface runoff and crop water use estimation. The conceptual and computational models of this approach are as shown in Figure 2.

From the expression above, provided there is readily available water, RAW for the oil palm, actual evapotranspiration,
AE becomes potential evapotranspiration, PE. From Figure 2, when the soil moisture falls below the threshold of RAW, the crops are under stress and the rate of transpiration is reduced except the rate of inflow into the soil exceeds the PE. If the soil moisture drops further to the level of TAW which corresponds to permanent wilting point, it then becomes difficult for plant roots to further extract soil water.

\section{Reference evapotranspiration ETo}

With the available maximum, minimum and mean temperature data with radiation, $R a$, the Hargreaves method of evapotranspiration estimation was used in this study. According to Droogers and Allen (2002), Hargreaves ETo equation can be expressed as:

$$
E T_{o}=0.0023\left(T_{\text {mean }}+17.8\right)\left(T_{\text {max }}-T_{\text {min }}\right)^{0.5} R a
$$

Where;

$$
\begin{array}{ll}
E T_{o} & =\text { the daily reference evapotranspiration }(\mathrm{mm} / \text { day }) \\
T_{\text {max }} & =\text { maximum daily temperatures respectively }\left({ }^{\circ} \mathrm{C}\right) \\
T_{\text {min }} & =\text { minimum daily temperatures respectively }\left({ }^{\circ} \mathrm{C}\right) \\
T_{\text {mean }} & =\text { Mean Temperature }\left({ }^{\circ} \mathrm{C}\right) \\
R a & =\text { Extraterrestrial radiation as } 16.4 \mathrm{MJm}^{2} / \text { day }
\end{array}
$$

(Shavalipour et al. 2013)

\section{Results}

Table 1 presents the crop and soil parameters for the soil moisture balance of oil palms. All the oil palms in the study area were already mature at the time of study and hence the use of maximum root depth of $0.9 \mathrm{~m}$ and crop stress coefficient $K_{c}$ of 1.0 .

\section{Runoff estimation from the HEC-HMS}

Curve number value of 40 and Lag-time of 60 minutes, with estimated impervious value of $17.64 \%$ were chosen after series of trials and these were further used in the validation processes. $\mathrm{CN}$ value of 40 and Lag-time of 60 minutes gave the ENs of 0.794 and $R^{2}$ value of 0.853 for April 23rd calibration which showed a good fit and as well above 0.5 thresholds. This also showed that the two-flow data were not significantly different and that the model predictions are as accurate as the mean of the observed data (Dongquan et al. 2009). Figures 3 shows the hydrographs of the calibrations carried out from the two flood events of April 7th and August 23 2014 water year. The two hydrographs indicate that the simulated flows reasonably predicted the recorded flow.
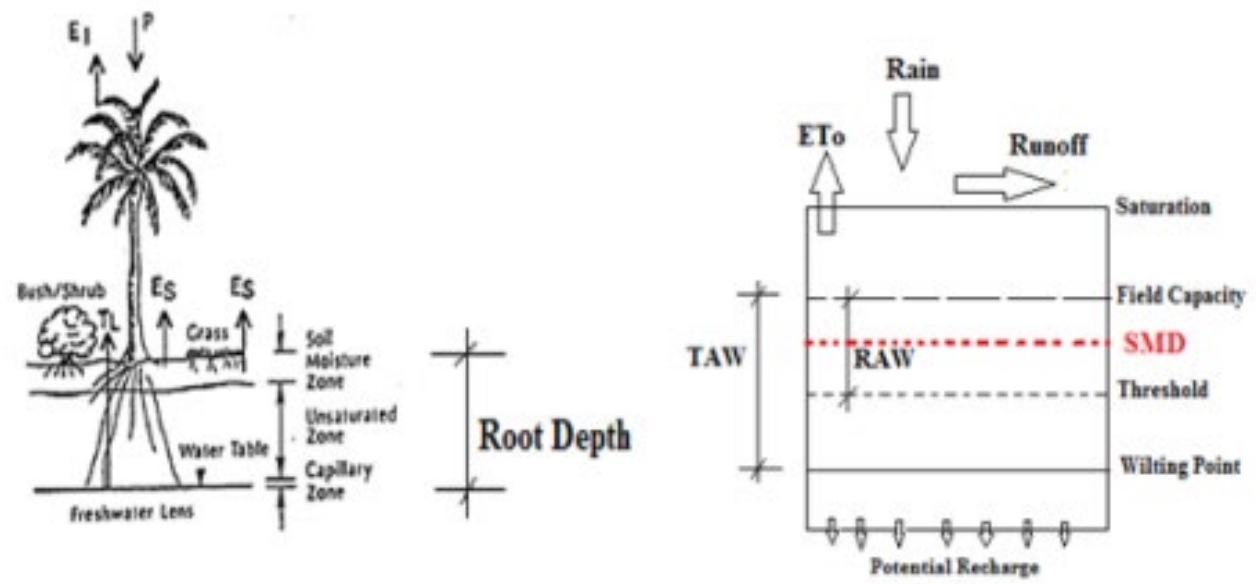

Figure 2. Conceptual and computational models of soil moisture balance 
Table 1. Crop and soil parameters for the soil moisture balance of oil palms study plots

\begin{tabular}{|c|c|c|c|c|}
\hline Parameters/Year of cultivation & 2000 & 2002 & 2006 & 2010 \\
\hline \multicolumn{5}{|l|}{ CROP PARAMETERS: } \\
\hline Maximum root depth (m) & 0.9 & 0.9 & 0.9 & 0.9 \\
\hline *Depletion factor & 0.70 & 0.70 & 0.70 & 0.70 \\
\hline$K c$ (initial) & 1.00 & 1.00 & 0.7 & 1.00 \\
\hline$K c$ (development) & 1.00 & 1.00 & 1.00 & 1.00 \\
\hline$K c$ (mild stage) & 1.00 & 1.00 & 1.00 & 1.00 \\
\hline Kc (late) & 1.00 & 1.00 & 1.00 & 1.00 \\
\hline \multicolumn{5}{|l|}{ SOIL PARAMETERS: } \\
\hline Bulk density $\left(\mathrm{gcm}^{-3}\right)$ & 0.302 & 0.217 & 0.276 & 0.397 \\
\hline$V M C @$ Saturation $\left(\mathrm{m}^{3} \mathrm{~m}^{-3}\right) \theta_{\text {sat }}$ & 0.53 & 0.51 & 0.52 & 0.52 \\
\hline \multicolumn{5}{|l|}{ 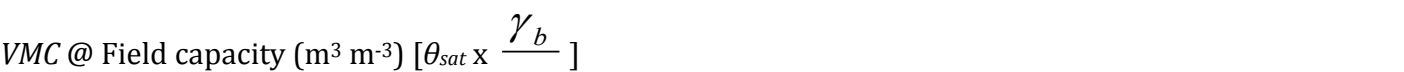 } \\
\hline$\gamma_{w}$ & 0.16 & 0.11 & 0.14 & 0.206 \\
\hline VMC @ Wilting Point $\left(\mathrm{m}^{3} \mathrm{~m}^{-3}\right)$ [FC/2.4] & 0.067 & 0.05 & 0.06 & 0.086 \\
\hline Maximum TAW $(\mathrm{mm})[\mathrm{FC}-\mathrm{WP}] / 900$ & 84 & 54 & 72 & 108.4 \\
\hline Maximum RAW (mm) [TAW*0.7] & 59 & 37.8 & 50.4 & 75.9 \\
\hline Soil Moisture Deficit (mm) & 83.9 & 54 & 72 & 108.4 \\
\hline *NSS Factor & 0.45 & 0.45 & 0.45 & 0.45 \\
\hline
\end{tabular}

* Depletion factor (Allen et al. 1998)

**NSS factor (Rushton et al. 2006)

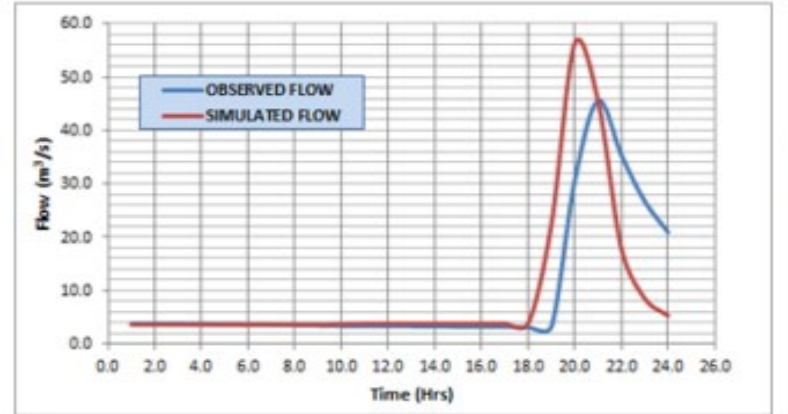

a)

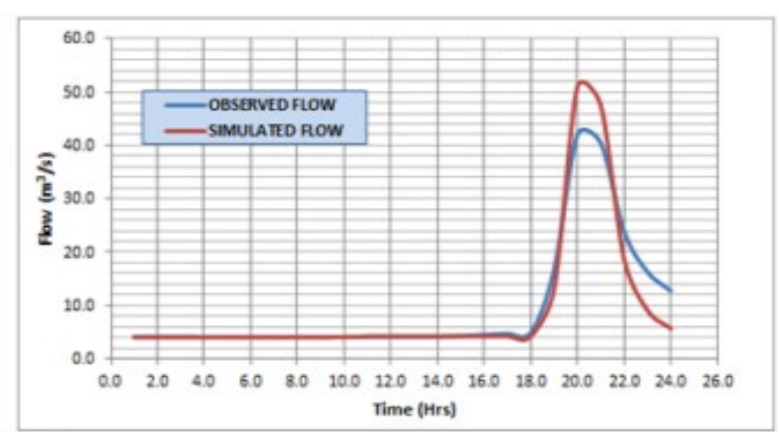

b)

Figure 3. Comparison of simulated and observed hydrographs for semenyih basin. a) April 7th 2014 flood event and b) August $23^{\text {rd }} 2014$ flood event

\section{Soil moisture balance model validation}

The adopted runoff coefficients from the previous sections were inserted into the model and the model was run for each of the study plots. Similar runoff hydrographs were observed from all the other plots, since the same rainfall pattern was used in all the sub-basins with similar soil and oil palm properties, though with different initial soil moisture deficit. Therefore, the values of $\boldsymbol{E}_{N S}$ and coefficient of determination $\boldsymbol{R}^{2}$ for all the study plots (for $20 \%$ increase in runoff coefficients) between the SMB Model and HEC-HMS Model flows gave acceptable values. This means the predicted discharge for the sub-basins fit the observed data well with Nash-Sutcliffe model efficiency of 0.54 and $\boldsymbol{R}^{2}$ ranging from 0.92 to 0.928 at the sub-watershed outlets (Tilahun et al. 2015).

\section{Interpretation of soil moisture balance model output parameters}

Graphical relationship among some important output parameters of the soil moisture balance model for study plot 2000 is presented in Figure 4. The most important among the parameters in the figures are the relationships between groundwater recharge, soil moisture deficit (SMD), reference evapotranspiration (ETo), total available water (TAW), readily available water (RAW) and surface runoff. In the figure, the shaded parts represent the periods of higher soil moisture dificits (SMD), where SMD > RAW.

The model recorded annual groundwater recharge which varied from $5 \mathrm{~mm}$ in 2010 study plot to $27 \mathrm{~mm}$ in 2002 study plot. Annual rainfall depth was $2135 \mathrm{~mm}$ while the annual runoff ranged from $1114 \mathrm{~mm}$ in 2006 to $1195 \mathrm{~mm}$ in 2002. Actual evapotranspiration, AE ranged from $881 \mathrm{~mm}$ in 2002 to $989 \mathrm{~mm}$ in 2006. Parts of this moisture are held up in the root zones which are readily available for crops use. They are termed readily available water (RAW). It is defined as the amount of water readily available for crop for extraction from its root zone (Steduto, 2012) and depends on soil types, depth and distribution of roots within the soil mass (Carr, 2011). Since it became evident that the peatlands in all the study plots experienced groundwater recharge late in the year, availability of soil moisture for oil palms' productivity in the root zone and avoiding peatland degradation became very crucial.

\section{Monthly soil moisture balance estimation}

The equation for the estimation of monthly water balance $(\Delta s)$ for all the study plots is as represented in [3]. This helps to estimate the monthly water balance status for each of the study plots in order to appraise the need to supplement rainfall in the event of any deficit in soil moisture to avoid water stress. 


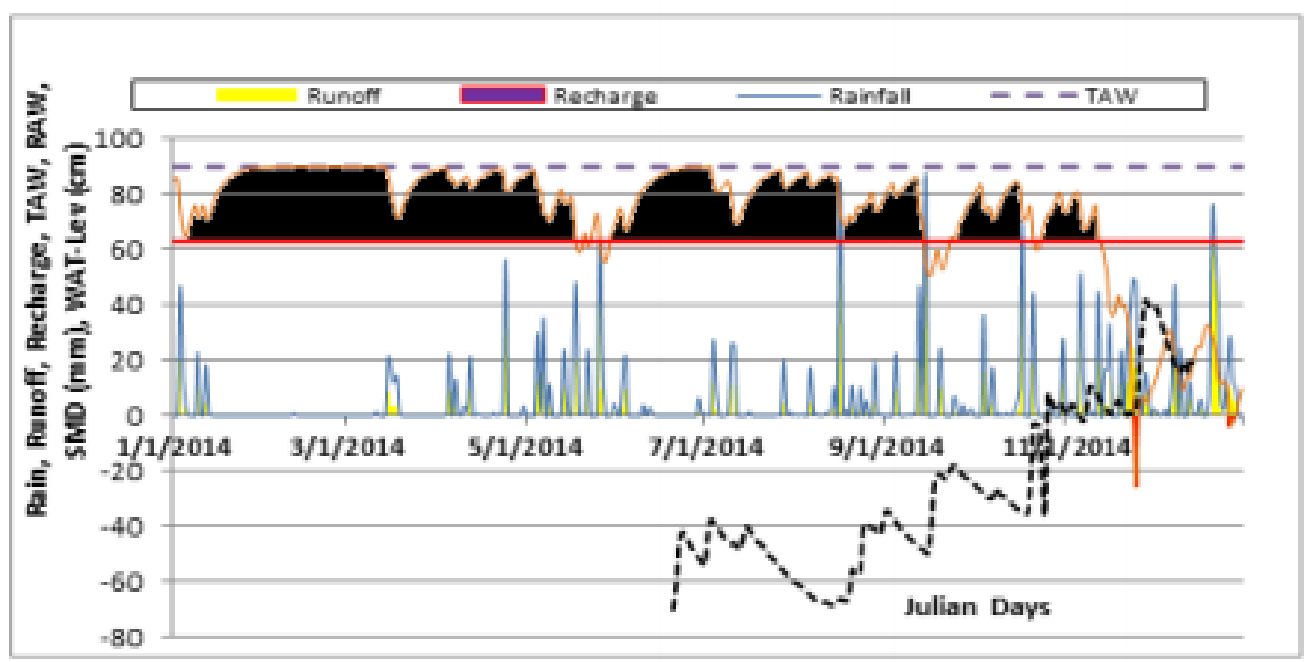

Figure 4. Soil moisture components for 2000-SITE representing 2014 water year

$$
\Delta s=[P+R A W]-\left[E T_{o}+Q+R e\right]
$$

Using Water Balance Equation to estimate the existing storage in the month of January for 2000 study plot;

$\Delta s=[P+R A W]-\left[E T_{o}+Q+R e\right]$

$\Delta s=[106+59]-[164.91+44.52+0]=-44.43 \mathrm{~mm}$ for January

$\Delta s=[1+59]-[156.78+0.42]=-97.2$ for February

Using this equation for all the study plots as presented in the tables, February recorded the highest water deficit in all the study periods and this could be attributed to the low total monthly rainfall depth of $1.0 \mathrm{~mm}$. 2002 study plot recorded the highest soil water deficit of $-118.2 \mathrm{~mm}$ because of low readily available water recorded as $38 \mathrm{~mm}$ followed by $-106.2 \mathrm{~mm}$ in 2006 study plot which recorded $50 \mathrm{~mm}$ as RAW. Peat fires recorded in 2006 study plot during this period was attributed to the excessive lowering of water table depth which was occasioned by low rainfall depth that resulted in high water deficit in the month of February.

\section{Peatland irrigation design and planning for study area}

For oil palm optimum productivity, required quantity of soil water depth from where crop roots extract soil water must be maintained (Michael, 2008). If the consumptive water use of crops exceed the rate at which soil is receiving water, then this will lead to water stress which would have serious implications on the crops productivity. According to Gleick and Palaniappan (2010), 'Such consumptive water uses include water that has been evaporated, transpired, incorporated into products or crops, heavily contaminated, or consumed by humans or animals.

\section{Oil palm's consumptive water use and irrigation designs}

In order to estimates the oil palms' consumptive water use for each study plot, days where SMD is greater than RAW are checked to examine the consumptive water use by the crops and comparing it with permissible withdrawal for the study plot. Once the oil palms' consumptive water use exceeds the field permissible withdrawal, there will be soil water deficit within the soil root zone which must be replenished (through irrigation) to avoid adverse effects of soil water stress on oil palms. Irrigation needs of the 2000 study plot is therefore estimated in the section below.

\section{Irrigation water design for 2000 Study plot}

From Figure 4, there are Four occasions when SMD > RAW; these are;

i. CASE I: Jan 1 -May 18 (138 days)

ii. CASE II: May 30 - Sept 13 (107 days)

iii. CASE III: Sept 22 - Oct. 22 (31 days)

iv. CASE IV: Oct 24 - Nov. 12 (20 days) design

CASE I with longer number of days was chosen for irrigation

\section{Consumptive crop water use for CASE I}

$E T_{o}=(5.13 * 3)+(5.34 * 34)+(5.67 * 22)+(5.46 * 79)=753.03 \mathrm{~mm}$

$E T_{\text {ocrop }}==1.0 * 753.03=753.03 \mathrm{~mm}$

$\begin{array}{ll}\text { Rainfall } & =476.5 \mathrm{~mm} \\ \text { Runoff } & =217.08 \mathrm{~mm} \\ \text { Recharge } & =0\end{array}$

Effective rainfall $=$ Rainfall - Runoff - Recharge

$=476.5-217.08-0$

$=259.52 \mathrm{~mm}$

Effective rainfall can also be expressed by;

Effective rainfall $=0.8 *$ Rainfall (with rainfall above 75 $\mathrm{mm} / \mathrm{month}$ ) (Dastane, 1978).

\section{To estimate whether there is deficit;}

Consumptive water use - Effective rainfall $=753.03-259.52$

$$
=493.51 \mathrm{~mm}
$$

This is far greater than the permissible withdrawal of 27.18 $\mathrm{mm}$ for 2000-Study plot, hence the need for irrigation.

$493.51>27.18$

Having confirmed the need for irrigation for CASE I, Field Irrigation Requirement (FIR), frequency of irrigation and the water depth required for irrigation between the periods in question.

Water Holding Capacity of Soil $=\mathrm{TAW}=84 \mathrm{~mm}$

Rooting depth $\quad=0.9 \mathrm{~m}$

Moisture Holding Capacity of root zone

$\frac{84 * 0.9}{1000}=0.0756=76 \mathrm{~mm}$

Allowable depletion (Allen et al. 1998) = $35 \%$ 


\section{STEP 1. Allowable depletion depth between irrigations}

$=0.35 * 76=26.6 \mathrm{~mm}=2.7 \mathrm{~cm}$

The daily consumptive use of water between Jan 1 to May $18=5.45 \mathrm{~mm} /$ day

STEP 2. Duration of irrigation (in days) between Jan 1 to May 18;

$\frac{\text { Available moisture }}{\text { Daily consumption }}=\frac{2.7}{0.55}=5$ days

This means irrigation will be needed after every 5 days from Jan 1 to May 18.

\section{STEP 3. Net Water depth required for irrigation each time after 6 days}

$5 * 0.55=2.75=3.0 \mathrm{~cm}$

This means $3.0 \mathrm{~cm}(30 \mathrm{~mm})$ depth or equivalence of 5.45 $\mathrm{mm} /$ day ( $165 \mathrm{~mm} /$ month) of irrigation water will be needed for 5 days at every irrigation period.

\section{STEP 4: Field Irrigation Requirement (FIR)}

Using the Irrigation Efficiency of $40 \%$ (Allen et al. 1998)

$F I R=\frac{\text { Net Irrigation Requirement }}{\text { Efficiency of Irrigation }}=\frac{3.0}{0.4}=7.5 \mathrm{~cm}$

This means $7.5 \mathrm{~cm}(75 \mathrm{~mm})$ depth of irrigation water will be needed per Area of field.

i.e. $7.5 \mathrm{~cm}$ per hectare

for 2000 study plot with $19.31 \mathrm{~km}^{2}$, the quantity of water required in the study plot;

Quantity of irrigation $=7.5 *$ Area of field $=0.075(\mathrm{~m}) * 19.31$ $\left(\mathrm{km}^{2}\right)$

$0.075 * 19310000=\mathbf{1 . 4 5} * \mathbf{1 0}^{\mathbf{6}} \mathbf{m}^{\mathbf{3}}$

Hence volume of water required to irrigate 1,931 ha of 2000 study plot at 16 days interval;

\section{$=1.45 * 10^{6} \mathrm{~m}^{3}$}

This is the amount of irrigation water needed in 6 days i.e

$1.45 * 106 \mathbf{m}^{3} / 6$ days $=\frac{1,450,000}{6 * 24 * 3600}=2.79 \mathrm{~m}^{3} / \mathrm{s}$

Table 2 shows the summary of irrigation requirements in all the study plots with the peatland properties. Study plot 2000 required the highest irrigation needs as a result of its size $(19.31$ $\mathrm{km}^{2}$ ). This is followed by study plot 2002 with $12.34 \mathrm{~km}^{2}$ as the area of the peatland. From Table $3,7.63 \mathrm{~m}^{3} / \mathrm{s}$ represents the total irrigation need of the study area with days varying from 4 to 7 days depending on the study plot.

\section{Discussion}

Soil moisture balance model has been used in this study to establish the water balance of the study area and to determine the irrigation need of the oil palms. Most prominent in the model application is the rainfall-runoff relationship of the study area being used. The major model input parameters are rainfall, crop evapotranspiration, available water for evaporation (AWE), crop rooting depth, depletion factor and near surface storage. The output parameters include surface runoff, soil moisture deficit, total available water, readily available water and groundwater recharge. Groundwater recharge and soil moisture deficit estimation became important in a bid to appraise the influence insufficient rainfall on the crop survival and production yield. In all the study plots groundwater recharge did not occur until late November. The first recharge in study 2000 was experienced on $25^{\text {th }}$ November 2014 with annual recharge varying from $5 \mathrm{~mm}$ in 2010 study plot to $27 \mathrm{~mm}$ in 2002 study plot. It was observed that most of the precipitation was lost to runoff as annual runoff from the study varied from $1114 \mathrm{~mm}$ in 2010 study plot which is about $53 \%$ of annual rainfall to $1195 \mathrm{~mm}$ in 2000 study plot (56\% of annual rainfall). The effects of not having enough water in the soil storage was observed particularly during the period of no recharge and the steps to follow in estimating the required irrigation needs in the event of high soil moisture deficit noted. Difficulty in applying the model is of great concerns. First, lack of real time measured data in the study area could not allow the rainfall-runoff relationship to be measured directly. Thus in this study, a nearby catchment (with gaging stations for both streamflow and rainfall) having similar vegetation and land use pattern with the study area was used in establishing rainfall-runoff relationship for the study area. The flow and rainfall data from this adopted catchment were used to calibrate and validate HEC-HMS rainfall-runoff model using a statistical analysis.

In all the study plots, February, March, April, May, June, July, August and some parts of October and November were observed to represents the periods with high irrigation needs as SMD > RAW throughout these periods. This has been attributed to many factors, among which are: low monthly rainfall depth, high runoff, high evapotranspiration and high surface temperature. Since the major parts of the water year requires no irrigation by the virtue of soil moisture availability and adequate storm events, deficit irrigation was recommended. Volume of water expected as irrigation requirements for the study plots ranged from $0.607 * 10^{6} \mathrm{~m}^{3}$ in 2006 study plot to $1.6 * 10^{6} \mathrm{~m}^{3}$ in 2000 study plot. Permissible withdrawal in each of the study plots also varied from $11.7 \mathrm{~mm}$ in 2002 study plot to $42.87 \mathrm{~mm}$ in 2000 study plot. In order to ensure adequate supply of water for irrigation purposes, the need to locate the source of such irrigation water is of high importance. There were two options available; the first is diverting water from Semenyih reservoir which have been tested for its irrigation potentials (Juahir et al. 2009) and the other option which was preferable due to its proximity to the study area was chosen.

Table 2. Irrigation requirement of oil palm plantation with peatland soil properties

\begin{tabular}{|c|c|c|c|c|c|c|c|}
\hline $\begin{array}{l}\text { Study } \\
\text { Plot }\end{array}$ & $\begin{array}{l}\text { Area } \\
\left(\mathrm{km}^{2}\right)\end{array}$ & $\begin{array}{l}\text { ETo. } \\
(\mathrm{mm})\end{array}$ & $\begin{array}{l}\text { Permissible } \\
\text { Withdrawal }(\mathrm{mm})\end{array}$ & $\begin{array}{l}\text { Freq of } \\
\text { Irrigation (day) }\end{array}$ & $\begin{array}{l}\text { Monthly Irrigation } \\
\text { Depth (mm) }\end{array}$ & $\begin{array}{l}\text { Field Irrigation } \\
\text { Required }\left(10^{6} \mathrm{~m}^{3}\right)\end{array}$ & $\begin{array}{l}\text { Field Irrigation } \\
\text { Required } \\
\left(\mathrm{m}^{3} / \mathrm{s}\right)\end{array}$ \\
\hline 2000 & 19.31 & 753.03 & 27.18 & 5 & 165 & 1.45 & 2.79 \\
\hline 2002 & 12.34 & 753.03 & 11.7 & 4 & 164 & 0.68 & 1.96 \\
\hline 2006 & 0.893 & 769.41 & 19.87 & 5 & 163.8 & 0.607 & 1.4 \\
\hline 2010 & 0.893 & 802.17 & 42.87 & 7 & 165 & 0.893 & 1.48 \\
\hline TOTAL & & & & & & & $7.63 \mathrm{~m}^{3} / \mathrm{s}$ \\
\hline
\end{tabular}




\section{Conclusion}

Irrigation and crop water requirement (CWR) estimation in a tropical peatland in oil palm plantation has been estimated for the 2014 water year. The need to ensure the adequate and constant soil moisture availability in the peatland for oil palm use in the absence of groundwater recharge is the basis behind this study. The study was able to estimate when and how much water is recharging the peatland water table. The study also examined the need for rainfall supplement in case of inadequacy of soil moisture in the root zones and thus estimate the irrigation need of the crops. Each study plot was examined separately and the periods when SMD > RAW was noted as the periods where the irrigation is required in the fields. In all the study plots, the thresholds of 50-75 cm water table depth below the peat surface as best management practice (BMP) for tropical peatland area was obtainable. The total amount of recharge estimated is site specific. In all the study plots, recharge occurred when the SMD $\leq 0$. This occurred when the field capacity was reached and there was free draining of soil water into the deep sub-surface causing a rise in water table depth. The use of nearby river Semenyih catchment $\left(35.38 \mathrm{~km}^{2}\right)$ and HECHMS software proved suitable for the study catchment. Establishing relationship between the two helped in adopting the HEC-HMS software in the study area along with the soil moisture balance model. This therefore, enabled the appropriate runoff coefficients to be used in soil-moisture balance model for reliable estimates of groundwater recharge and runoff for the study areas. And in conclusion, for proper water management practice, early detection of oil palm evapotranspiration demand will help in observing irrigation need and in controlling irrigation scheduling, effective irrigation planning and savings of water resources. HEC-HMS and SMB models have been used successfully for on-point and immediate oil palm water deficit estimation. However, the application of soil moisture balance model for future oil palm water deficit estimation to forestall oil palm water stress and for adequate oil palm plantation water resources planning would be recommended for future studies. On-site oil palm plantation management would also help in reducing costs associated with plantation irrigation. From the study, it would be observed that in the months of February, March, June, July, August and September, all in 2014, peatlands in the study area and indirectly, the oil palms experienced water deficit. This means, during these months in the subsequent water years, adequate water availability to all the oil palms in the plantation must be a priority to prevent oil palm water stress.

\section{Acknowledgment}

The authors wish to appreciate the efforts of Tertiary Education Trust Fund (TETFund) of The Federal Republic of Nigeria for the funding of this research and the Department of Civil Engineering, Universiti Putra Malaysia for the provision of the facilities needed for the success of the study.

\section{Author contributions}

Adesiji, Adeolu Richard, Asogwa, Evarestus Osita and Adaudu, Ignatius Idoko carried out the literature review and performed the main writing part. Nik Norsyahariati Nik Daud supported the study by providing the concept and structure of the manuscript, proof-read the whole manuscript and supervised the study as well as giving her advice on the manuscript. Musa, Hassan Hassan And Mangey, Jarumi Akila also edited the final manuscript and were involved in the statistical aspect of the study.

\section{Conflict of interests}

The authors declare that there is no conflict of interests to disclose that might be perceived as affecting the objectivity of this study.

\section{References}

Abdulkarim, B., Yacob, M. R., Abdullah, A. M., and Radam, A. 2017. Households' preferences and Willingness to Pay for Watershed Services Attributes In North Selangor Peat Swamp Forest Malaysia. Asian Journal of Economic Modelling, 5(1): 98-109.

Adila N., Sasidhran S., Kamarudin N., Puan C. L., Azhar B., Lindenmayer D. B. 2017. Effects of peat swamp logging and agricultural expansion on species richness of native mammals in Peninsular Malaysia. Basic and Applied Ecology. 22:1-10.

Allen, R. G., Pereira, L. S., Raes, D., and Smith, M. 1998. Crop Evapotranspiration: Guidelines for Computing Crop Water Requirements. Irrigation and Drainage Paper 56. UN-FAO, Rome, Italy.

Avinash, A., Subramaniam, D., and Murugesan, A. 2014. "Biodiesel-A global scenario." Renewable and sustainable energy reviews 29: 517-527.

Awulachew, S. B., Philippe, L. P., and Tulu, T. 2009. Soil-plantwater relationships. International Livestock Research Institute (ILRI), Addis Ababa, Ethiopia

Carr, M. K.V. 2011. The water relations and irrigation requirements of oil palm (elaeis guineensis): a review. Experimental Agriculture, 47:629-652. doi:10.1017/S0014479711000494.

Chen, Y., Xu, Y., Yin, Y. 2009. Impacts of land use change scenarios on storm-runoff generation in Xitiaoxi Basin, China. Quat. Int. 208:121-128.

De Silva, C. S., Rushton, K. R. 2007. Groundwater recharge estimation using improved soil moisture balance methodology for a tropical climate with distinct dry seasons. Hydrological Sciences Journal, 52:1051-1067.

Dongquan, Z, Jining, C, Haozheng, W, Qingyuan, T, Shangbing, C, Zheng, S. 2009. GIS-Based Urban Rainfall-Runoff Modeling Using an Automatic CatchmentDiscretization Approach: A Case Study in Macau. Environmental Earth Sciences 59(2):465-472, doi: 10.1007/s12665-009-0045-1.

Droogers, P., and Allen, R. G. 2002. Estimating reference evapotranspiration under inaccurate data conditions. Irrigation and drainage systems, 16(1):33-45.

Gleick, P. H., and Palaniappan, M. 2010. Peak water limits to freshwater withdrawal and use. Proceedings of the National Academy of Sciences,107(25), 11155-11162.

Harahap, I. Y., and Darmosarkoro, W. 1999. Pendugaan kebutuhan air untuk pertumbuhan kelapa sawit di lapang dan aplikasinya dalam pengembangan sistem irigasi [Estimation water needs for growing oil palm in field and its application in the development of the system irrigation]. Iurnal Penelitian Kelapa Sawit, 7, 87-104.

Juahir, H., Zain, S. M., Khan, R. A., Yusoff, M. K., Mokhtar, M. B., and Toriman, M. E. 2009. Using chemometrics in assessing Langat River water quality and designing a costeffective water sampling strategy. Maejo International Journal of Science and Technology, 3(01), 26-42

Kamlun K. U., Arndt, R. B., Phua, M. H. 2016. Monitoring deforestation in Malaysia between 1985 and 2013: Insight from South-Western Sabah and its protected peat swamp area. Land Use Policy, 57:418-430.

Karthikeyan, L., Kumar, D. N., Graillot, D., Gaur, S. 2013. Prediction of ground water levels in the uplands of a 
tropical coastal riparian wetland using artificial neural networks. Water resources management, 27(3):871883.

Katimon, A., Shahid, S., Khairi, Abd Wahab, A., Ali, M. H. 2013. Hydrological behaviour of a drained agricultural peat catchment in the tropics. 1: Rainfall, runoff and water table relationships. Hydrological Sciences Journal, 58(6):1297-1309.

Lim, K. H., Lim, S. S., Parish, F. Suharto, R. (eds) 2012. RSPO Manual on Best Management Practices (BMPs ) for Existing Oil Palm Cultivation on Peat. RSPO, Kuala Lumpur. Available at www.academia.edu/7783645/RSPO_Manual_on_Best _Management_Practices_BMPs_for_Oil_Palm_Cultivati on_on_Peat. Accessed on 3rd October, 2017

May, C. Y. 2012. Malaysia: economic transformation advances oil palm industry. AOCS (American Oil Chemists' Society).

Melling, L., Goh, K. J., Chaddy, A., Hatano, R. 2014. Soil CO2 Fluxes from Different Ages of Oil Palm in Tropical Peatland of Sarawak, Malaysia. In Soil Carbon (pp. 447-455). Springer International Publishing.

Michael, A. M. 2008. Irrigation: theory and practice. Vikas Publishing House Pvt Ltd.

Naderi, M., Shayannejad, M., Heydari, S., and Haghighati B. 2016. Effect of different levels of irrigation water on quantitative and qualitative Journal of Water and Soil 30(5).

Querner, E. P., Jansen, P. C., Van den Akker, J. J. H., Kwakernaak, C. 2012. Analysing water level strategies to reduce soil subsidence in Dutch peat meadows. Journal of hydrology, 446:59-69.

RSPO. 2012. Roundtable on Sustainable Palm Oil (RSPO). Available http://www.sustainablepalmoil.org/standardscertfication/certification-schemes/the-roundtableon-sustainable-palm-oil-rspo/, accessed on 12th July, 2015.

Rushton, K. R., Eilers, V. H. M., Carter, R. C. 2006. Improved Soil Moisture Balance Methodology for Recharge Estimation. Journal of Hydrology, 318:379-399.

Schilling, K. E. 2007. Water table fluctuations under three riparian land covers, Iowa (USA). Hydrological Processes, 21(18):2415-2424.

Seo, J. Y., Lee, S. -I. 2015. Multi-Platform Satellite Based Estimates of Runoff in Ungauged Areas. ISPRSInternational Archives of the Photogrammetry, Remote Sensing and Spatial Information Sciences: 6162.

Shavalipour, A., Hakemzadeh, M. H., Sopian, K., Mohamed H. S., Zaidi, S. H. 2013. New formulation for the estimation of monthly average daily solar irradiation for the tropics: a case study of Peninsular Malaysia. International Journal of Photoenergy, 2013.

Shao, M., Jing, X., and Wang, L. 2015. Object-based Analysis for Extraction of Dominant Tree Species. Asian Agricultural Research, 7(7):57.

Steduto, P. 2012. Crop yield response to water (pp. 192-201). Rome: Food and Agriculture Organization of the United Nations.

Tilahun, S. A., Guzman, C. D., Zegeye, A. D., Dagnew, D. C., Collick, A. S., Yitaferu, B., Steenhuis, T. S. 2015. Distributed discharge and sediment concentration predictions in the sub-humid Ethiopian highlands: the Debre Mawi watershed. Hydrological Processes, 29(7):1817-1828. 